\title{
Meat Production Potential of Small Ruminants Under the Arid and Semi-arid Conditions of Pakistan
}

\author{
Mohamed Fatah Ullah Khan* and Faisal Ashfaq \\ Small Ruminants Research Program, Animal Sciences Institute, \\ National Agricultural Research Centre, Park Road, Islamabad-45500, Pakistan
}

إمكانات إنتاج اللحوم من المجترات الصغيرة تحت الظروف الجافة وشبه الجافة في باكستان

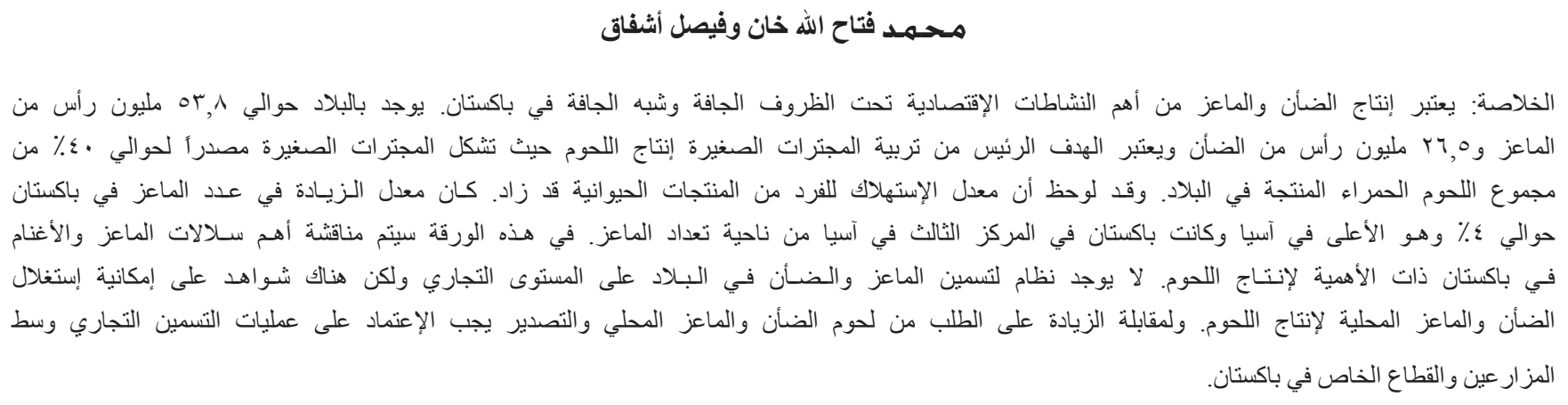

\begin{abstract}
Sheep and goat production is one of the major economic activities under the arid and semi-arid condition of Pakistan. The country has 53.8 million goats and 26.5 million sheep. The main purpose of raising these small ruminants in the country is meat production. The small ruminants share about $40 \%$ of total red meat produced in the country. It has been observed that in the last several years the overall per capita consumption of the animal food products is increasing. Overall annual growth rate of goats in Pakistan is $4 \%$, which is the highest in Asia. Pakistan ranks third in Asia in small ruminant population. Some famous sheep and goat breeds of Pakistan which have potential for mutton production will be discussed in the paper. There is no feedlot fattening system functioning in the country on a commercial level. The indicators suggest that there are good prospect for sheep and goat to be used as meat animals. In order to meet the increasing demand of mutton locally as well as for export, feedlot operations are required to be introduced among the farmer communities and in the private sector in Pakistan.
\end{abstract}

Keywords: Feedlot, mutton, goat breeds, Pakistan.

\section{Introduction}

Small ruminants contribute largely to the livelihoods of the livestock-keeping households of low and medium income farmers in the developing world. The keeping of small ruminants is mainly concentrated in the developing areas of the world.

Small ruminants make up a large proportion of the domestic ruminants in Asia in terms of numbers and in contribution to meat production. Asia accounts for $52 \%$ of the world's small ruminant population as reported in Table 1 (FAOSTAT, 2006).

In Pakistan small ruminants (sheep and goats) are raised by landless or poor farmers with minimum landholdings. Pakistan has about 34 goat and 28 sheep breeds (Isani and Baloch, 1996). The majority of sheep and goat breeds in Pakistan are meat type animals. Some breeds like Beetal, Dera Din Panah (DDP), Kamori, Nachi and Damani are known as dairy goat breeds but are not comparable to the improved dairy goat breeds from Europe and North America. The meat supplied by small ruminants is preferred over meat from large ruminants in Pakistan particularly, goat meat. Moreover, the value of goat meat is higher than the meat supplied by sheep and any other livestock species such as cattle and buffalo.

\section{Growth Dynamics and Distribution of Small Ruminants}

Sheep and goats make up a large population of domestic animals in Pakistan. The population of sheep and goats and their overall growth is presented in Table 2.

According to Pakistan National Livestock Census (2006) goat has the highest growth rate of $3.98 \%$ per annum among all the domestic livestock in Pakistan. Sheep has a growth rate of $0.84 \%$ per annum, lowest among the livestock. According to the FAOSTAT (2006), goats in Pakistan are increasing at a rate of $3.78 \%$ annually, which is the highest in 
Table 1. Population of small ruminants in the world and major countries in Asia (Million heads).

\begin{tabular}{lcccccc}
\hline \multirow{2}{*}{ Region } & \multicolumn{2}{c}{1996} & & \multicolumn{2}{c}{2005} \\
\cline { 2 - 7 } & Sheep & Goat & Sheep & Goat & Sheep & Goat \\
\hline World & 1060.01 & 689.43 & 1053.64 & 722.15 & 1079.73 & 807.24 \\
Asia & 411.94 & 441.84 & 414.40 & 454.24 & 456.65 & 519.29 \\
China & 127.63 & 149.91 & 131.09 & 148.40 & 170.88 & 195.76 \\
India & 55.29 & 119.48 & 59.60 & 121.40 & 62.50 & 120.00 \\
Pakistan & 23.54 & 41.17 & 24.08 & 47.43 & 24.90 & 56.70 \\
\hline
\end{tabular}

Source: FAOSTAT, 2006.

Asia. The reason for the higher annual growth rate of goat is the national preference for goat meat as compared to the meat of other ruminants. Moreover, the higher growth rate of the goat population can also be attributed to their suitability to the environment and their twinning ability.

Punjab has the highest goat population (37\%) followed by Sindh (23\%) Baluchistan $(22 \%)$ and NWFP $(18 \%)$ as shown in Table 2, whereas Baluchistan has the highest sheep population (48\%) followed by Punjab (24\%), Sindh $(15 \%)$ and NWFP (13\%).

After 1998, in the opinion of the authors, the sheep population has further decreased in Baluchistan Province due to persistent drought between 1998-2000. It has been

Table 2. Population and growth trend of small ruminants in Pakistan (Million heads).

\begin{tabular}{|c|c|c|c|c|}
\hline Province & 1986 & 1996 & 2006 & $\begin{array}{c}\% \\
\text { Annual } \\
\text { growth } \\
\text { rate }\end{array}$ \\
\hline \multicolumn{5}{|l|}{ Punjab } \\
\hline Sheep & 6.69 & 6.11 & $6.36(24 \%)$ & -0.25 \\
\hline Goat & 10.76 & 15.24 & $19.83(37 \%)$ & +4.21 \\
\hline \multicolumn{5}{|l|}{ Sindh } \\
\hline Sheep & 2.62 & 3.76 & $3.96(15 \%)$ & +2.56 \\
\hline Goat & 6.76 & 9.89 & $12.57(23 \%)$ & +4.30 \\
\hline \multicolumn{5}{|l|}{$N W F P$} \\
\hline Sheep & 2.23 & 2.82 & $3.36(13 \%)$ & +2.55 \\
\hline Goat & 4.20 & 6.59 & $9.60(18 \%)$ & +6.45 \\
\hline \multicolumn{5}{|c|}{ Baluchistan } \\
\hline Sheep & 11.11 & 10.81 & $12.80(48 \%)$ & +0.75 \\
\hline Goat & 7.30 & 9.48 & $11.78(22 \%)$ & +3.05 \\
\hline \multicolumn{5}{|l|}{ Total } \\
\hline \multicolumn{5}{|l|}{ Pakistan } \\
\hline Sheep & 22.69 & 23.54 & 26.48 & +0.84 \\
\hline Goat & 29.95 & 41.20 & 53.78 & +3.98 \\
\hline
\end{tabular}

Source: Pakistan National Livestock Census, 1986, 1996 and 2006. estimated that $30 \%$ of the total livestock population has been lost due to drought (Azam, 2005).

There is substantial increase in the total population of small ruminants over the last twenty years. However, this increase is in the number of animals rather than a per head increase of the produce.

\section{Sheep and Goat Breeds}

Pakistan has 28 breeds of sheep and 34 breeds of goat which are listed below in Tables 3 and 4.

A lot of variation exists in characteristics among various sheep and goat breeds. Sheep breeds differ from thin tailed to fat tailed sheep and more variation exists in growth and wool production. Similarly, goat breeds differ in growth, reproduction and milk production. Goats are also kept primarily for meat production. Some goat breeds such as Beetal, Dera Din Panah, Nachi and Kamori are known as milk breeds. These are breeds whose meat is also most liked in their respective areas, especially Beetal and Kamori. Therefore, these breeds are known as dual purpose. Teddy is a small size breed, which has gained wide distribution and popularity over the last 30 years because of its prolificacy and faster growth rate.

\section{Meat and Goat Production}

Total meat production from small ruminant in Asia has been presented in Table 5 .

The Asian continent contributes $61 \%$ of the total mutton and goat meat produced in the world. China produces 54\% of total mutton and goat meat in Asia. Pakistan ranks third in Asia for mutton and goat meat production after India. For the last two years, India's mutton and goat meat production is maintained at a consistent level. Pakistan contributed about $7 \%$ of mutton and goat meat produced in Asia (FAOSTAT, 2006).

There is no system of producing mutton and goat meat on scientific and commercial lines that is common in the developed countries and this system is known as feedlot fattening. Almost all the mutton production is supplied from the conventional production system with minimum nutrition inputs and thus the carcass weight is usually low 
Table 3. Sheep breeds in Pakistan $(n=28)$.

\begin{tabular}{lrl}
\hline \multicolumn{1}{l}{ Punjab } & 7 & $\begin{array}{l}\text { Buchi, Lohi, Thalli, Kajli, Cholistani, Salt } \\
\text { Range, Sipli }\end{array}$ \\
Sindh & 3 & $\begin{array}{l}\text { Dumbi, Kachhi, Kooka } \\
\text { NWFP }\end{array}$ \\
Baluchistan & 4 & $\begin{array}{l}\text { Balkhi, Damani, Kaghani, Hashtnagri, } \\
\text { Michni, Tirahi, Waziri }\end{array}$ \\
$\begin{array}{l}\text { Northern area } \\
\text { and AJK }\end{array}$ & 7 & $\begin{array}{l}\text { Baltochi, Bibrik, Harnai, Rakhshani } \\
\text { Pahari, Poonchi }\end{array}$ \\
\hline
\end{tabular}

Source: Isani and Baloch, 1996.
Table 4. Goat breeds in Pakistan $=34$.

\begin{tabular}{|c|c|c|}
\hline Punjab & 4 & Beetal, Dera Din Panah, Nachi, Teddy \\
\hline Sindh & 14 & $\begin{array}{l}\text { Barbari, Kamori, Chappar, Bari, Bugi } \\
\text { Toori, Sindh Desi, Bujri, Jattan, Kacchan, } \\
\text { Kurri, Lohri, Pateri, Tapri, Tharki }\end{array}$ \\
\hline NWFP & 3 & Kaghani, Damani, Gaddi \\
\hline Baluchistan & 3 & Lehri, Khurasni, Kajli \\
\hline $\begin{array}{l}\text { Northern area } \\
\text { andAJK }\end{array}$ & 10 & $\begin{array}{l}\text { Baltistani, Beiari, Buchi, Jararkheil, Jattal, } \\
\text { Kohai-Ghizer, Kooti, Labri, Pamiri, Shurri }\end{array}$ \\
\hline
\end{tabular}

Source: Isani and Baloch, 1996.

Table 5. Comparative meat production (Million tons).

\begin{tabular}{|c|c|c|c|c|c|c|}
\hline & \multicolumn{2}{|c|}{1996} & \multicolumn{2}{|c|}{2000} & \multicolumn{2}{|c|}{2005} \\
\hline & Sheep & Goat & Sheep & Goat & Sheep & Goat \\
\hline World & 7.02 & 3.09 & 7.59 & 3.73 & 8.44 & 4.53 \\
\hline Asia & 2.98 & 2.11 & 3.48 & 2.67 & 4.50 & 3.41 \\
\hline China & 1.00 & 0.81 & 1.44 & 1.30 & 2.40 & 1.90 \\
\hline India & 0.21 & 0.45 & 0.22 & 0.46 & 0.24 & 0.47 \\
\hline Pakistan & 0.15 & 0.28 & 0.16 & 0.31 & 0.17 & 0.37 \\
\hline
\end{tabular}

Source: FAO, 2006.

compared to the potential present in some of our sheep and goat breeds. Absence of feedlot fattening is one of the major constraints against a higher quality and quantity of meat production.

In Pakistan total mutton and goat production is 782 thousand tons as shown in Table 6. It accounts for 40 percent of total red meat production in the country (Anonymous, 2006).

The slaughtered number of sheep and goats was about 15.73 million heads. Of the total meat production in Pakistan, 69.5\% is contributed by goats (Anonymous, 2007). When total mutton production data from 1976 to 1996 was reviewed, the mutton and goat meat production increased at a rate of 4.59 percent per annum (Khan et al., 2003). Later increase in mutton and goat meat per year is about $2-3 \%$ (Table 6 ). It means that mutton and goat meat production has increased at a slower rate than the previous years.

Comparison of per capita meat consumption $(\mathrm{kg})$ indicates a growing demand for meat in Pakistan in the years to come (Table 7). This relates to the increasing population growth and the prevailing livestock production systems.

\section{Growth and Fattening of Small Ruminants}

Planned studies on the growth rate of sheep and goats at different ages have not been undertaken. However, some information has been taken on different sheep and goat breeds maintained at the state livestock farms and these were reported by Hasnain (1985), Isani and Baloch (1996). Birth weight, weaning weight, mature body weight and dressing percentage of selected sheep and goats breeds found in different parts of country are presented in Tables 8 and 9 .

In the previous papers, only those sheep and goat breeds have been reported which have an adult body weight not less than $30 \mathrm{~kg}$. Among sheep breeds in Pakistan Kajli and Lohi sheep breeds have the highest adult body weight and these breeds have the highest daily growth rate. A similar observation was also made by Ahmed and Rehman (1996) who reported the highest growth rate in Kajli sheep in their experiments under farm conditions. Most of the sheep breeds have a carcass percentage between 45 to $55 \%$, which means that these breeds are not fed efficiently.

Similarly, the mature body weight of ten selected goat breeds of Pakistan which have a good meat production potential are reported in the paper. Isani and Baloch (1996) reported the highest weaning weight of 30 to 36 $\mathrm{kg}$ in the male of Jattan and Kacchan and Kamori breeds, which have the highest growth rate of $270 \mathrm{~g} / \mathrm{day}$. On the other hand, goat breeds of Punjab like Beetal, Dera Din Panah and Nachi have a weaning weight of 25, 25 and $15 \mathrm{~kg}$ in male kids respectively, as reported by Hasnain (1985). Growth rate/day of these breeds are 177, 185 and 
Table 6. Meat production from small ruminants in Pakistan (000 tons).

\begin{tabular}{lccc}
\hline Source of meat & $1995-96$ & $2005-06$ & $\begin{array}{c}\text { \% Annual increase } \\
(1996-2006)\end{array}$ \\
\hline Sheep & 214 & 238 & 1.12 \\
Goat & 374 & 544 & 4.54 \\
Total of Pakistan & 588 & 782 & 3.30 \\
\hline
\end{tabular}

Source: Anonymous, 2006.

Table 7. Per capita meat consumption (kg/annum).

\begin{tabular}{lccc}
\hline Countries & 1983 & 1993 & 2020 \\
\hline Developed world & 74 & 76 & 83 \\
Developing world & 14 & 21 & 30 \\
Pakistan & 11 & 16 & 47 \\
\hline
\end{tabular}

Source: Anonymous, 2003.

$107 \mathrm{~g}$ under traditional farming system. The average daily weight gain of Damani and Nachi usually ranged from 50$70 \mathrm{~g} /$ day (Khan et al., 2003) under rangeland conditions which is lower than their genetic potential. Most goat breeds, like sheep breeds found in Pakistan, have 50\% dressing percentage which is high as compared to Indian goat breeds like Beetal, Jamnapari and Serohi (Acharya, 1988).

The mutton and goat production gap between the conventional farming system and commercial farming system is significantly wide. Under traditional farming system of Pakistan, small ruminant's weight gain ranges from 50-70 grams, whereas daily weight gain under balanced feeding and management program reported by
Hasnain (1985) in Beetal is 247, Nachi 359 and DDP 134 g/day. An improved system of production like energy and protein supplementation in feed resulted in an increase in the reproduction performance, survivability and growth rate in small ruminants (Rafiq et al., 2003).

Similarly, the average daily gain (ADG) can be improved by $61-141 \%$ and the carcass weight by $34-79 \%$ owing to improved feeding management. In fact according to the review of Wilson (1992), feeding is one of the most important factors to influence meat production and carcass quality of small ruminants. However, in tropical less-developed countries, because of the high cost of concentrate, solutions must be aimed at developing new feeding strategies.

The range in productivity and ADG illustrates existing possibilities for higher animal performances through a combination of nutrition management and breeding of adapted genotypes. Results of some selected studies under improved feeding and management are given in Table 10.

\section{Potential of Sheep and Goat as Meat Animals}

The primary objective of sheep and goat farming in Pakistan is meat production maintained under different production systems. Under the traditional production system, growth rate per day of these species is very low with respect to their genetic potential.

Few planned studies on the fattening potential of sheep and goat have been conducted at the Livestock Production Research Institute (LPRI) Okara and National Agricultural Research Centre, Islamabad. The main findings of these studies are reported in Tables 11 and 12.

Khan et al. (2003) conducted some fattening trials on male Beetal kids, crossbred goat under field conditions and the data on these trials are presented in Table 12. These animals were fed on a ration having $20 \%$ roughage and $80 \%$ concentrate and having 15-16\% Crude Protein

Table 8. Production traits of selected sheep breeds in Pakistan.

\begin{tabular}{|c|c|c|c|c|c|c|}
\hline Breeds & Province & Birth Wt (kg) & Weaning wt (kg) & $\begin{array}{c}\text { Growth rate } \\
(\mathrm{g} / \mathrm{d})\end{array}$ & Adult wt (kg) & $\begin{array}{c}\text { Dressing } \\
\text { percentage }\end{array}$ \\
\hline Kail & AJK & 2.5 & 15.0 & 104 & 41 & 45 \\
\hline Baluchi & Baluchistan & 3.0 & 21.5 & 154 & 38 & 45 \\
\hline Balkhi & NWFP & 3.5 & 22.5 & 158 & 55 & 50 \\
\hline Kajli & Punjab & 4.0 & 21.5 & 146 & 78 & 55 \\
\hline Lohi & Punjab & 3.3 & 21.0 & 149 & 61 & 50 \\
\hline Salt Range & Punjab & 3.0 & 21.0 & 150 & 35 & 45 \\
\hline Thalli & Punjab & 3.7 & 20.0 & 137 & 35 & 50 \\
\hline Dumbi & Sindh & 3.0 & 20.0 & 142 & 40 & 40 \\
\hline Kachhi & Sindh & 3.1 & 22.5 & 162 & 42 & 50 \\
\hline Kooka & Sindh & 4.0 & 26.0 & 183 & 52 & 45 \\
\hline
\end{tabular}

Source: Isani and Baloch, 1996; Qureshi et al., 2002; Rafiq et al., 2003; Shah and Khan, 2004. 
Table 9. Production traits of selected goat breeds in Pakistan.

\begin{tabular}{|c|c|c|c|c|c|c|}
\hline Breeds & Province & Birth Wt (kg) & $\begin{array}{l}\text { Weaning wt } \\
(\mathrm{kg})\end{array}$ & $\begin{array}{l}\text { Growth rate } \\
(\mathrm{g} / \mathrm{d})\end{array}$ & Adult wt (kg) & $\begin{array}{c}\text { Dressing } \\
\text { percentage }\end{array}$ \\
\hline Gaddi & NWFP & 2.8 & 23.6 & 173 & 50 & 50 \\
\hline Beetal & Punjab & 3.7 & 25.0 & 178 & 46 & 50 \\
\hline Dera Din Panah & Punjab & 2.7 & 25.0 & 186 & 45 & 50 \\
\hline Nachi & Punjab & 2.0 & 15.0 & 108 & 45 & 45 \\
\hline Teddy & Punjab & 1.6 & 12.0 & 80 & 32 & 50 \\
\hline Jattan & Sindh & 3.5 & 36.0 & 271 & 78 & 50 \\
\hline Kacchan & Sindh & 3.5 & 35.0 & 263 & 68 & 48 \\
\hline Kamori & Sindh & 3.5 & 35.0 & 263 & 72 & 50 \\
\hline Kurri & Sindh & 3.0 & 24.0 & 175 & 50 & 50 \\
\hline Pateri & Sindh & 3.6 & 30.0 & 178 & 70 & 45 \\
\hline
\end{tabular}

Source: Isani and Baloch, 1996; Hasnain, 1985.

Table 10. Effect of system of production on growth and carcass characteristics.

\begin{tabular}{llccc}
\hline Authors and conditions & Variable & $\begin{array}{c}\text { Traditional } \\
\text { system }\end{array}$ & $\begin{array}{c}\text { Improved } \\
\text { management }\end{array}$ & $\begin{array}{c}\text { Improvement } \\
\text { (\%) }\end{array}$ \\
\hline Wilson (1992): (hay/concentrate ratio: 40/60 vs. 20/80) & Dressing percentage & 38 & 49 & 29 \\
& Fat thickness (mm) & 1.6 & 3.8 & 137 \\
Moniruzzaman et al. (2002): Black Bengal in Bangladesh & Slaughter weight (kg) & 9.0 & 12.3 & 37 \\
& Hot carcass weight (kg) & 3.4 & 5.2 & 53 \\
& Dressing percentage & 34 & 42 & 23 \\
Rafiq et al. (2003): Salt Range & Daily weight gain (g/d) & 112 & 131 & 16 \\
Alexandre et al. (2004): Creole, Africa & Weaning weight (kg) & 7.6 & 9.0 & 20 \\
Khan et al. (2006): Balkhi sheep & Daily weight gain (g/d) & 36 & 87 & 141 \\
& Hot carcass weight (kg) & 6.5 & 8.7 & 34 \\
\hline
\end{tabular}

Table 11. Fattening potential

\begin{tabular}{lcccccc}
\hline Breeds & Nos. of animal & $\begin{array}{c}\text { Age } \\
(\text { month })\end{array}$ & $\begin{array}{c}\text { Final Bwt, } \\
(\mathrm{kg})\end{array}$ & $\begin{array}{c}\text { D.Wtg, } \\
(\mathrm{g} / \mathrm{d})\end{array}$ & $\begin{array}{c}\text { Total wt gain } \\
(\mathrm{kg})\end{array}$ & FCR \\
\hline Thalli & 30 & 4 & 38.1 & 119 & 14.6 & 13.8 \\
Lohi & 30 & 4 & 36.3 & 125 & 12.5 & 11.7 \\
Kajli & 30 & 4 & 37.1 & 109 & 11.5 & 11.2 \\
Beetal & 30 & 4 & 30.1 & 67 & 10.5 & 15.7 \\
Dera Din Panah & 30 & 4 & 30.6 & 62 & 9.1 & 13.8 \\
Teddy & 30 & 4 & 17.2 & 40 & 5.7 & 16.2 \\
\hline
\end{tabular}

CP: $14 \%$, TDN: $71 \%$

Source: Khan and Pasha, 1990. 
Table 12. Fattening of sheep and goats under intensive feeding system.

\begin{tabular}{|c|c|c|c|c|c|c|c|c|}
\hline Breeds & Days & $\begin{array}{l}\text { Nos. of } \\
\text { animal }\end{array}$ & $\begin{array}{c}\text { Age } \\
\text { (months) }\end{array}$ & $\begin{array}{c}\text { Initial } \\
\text { BWt, (kg) }\end{array}$ & $\begin{array}{c}\text { Final Bwt, } \\
(\mathrm{kg})\end{array}$ & $\begin{array}{c}\text { DWG } \\
(\mathrm{g} / \mathrm{d})\end{array}$ & $\begin{array}{l}\text { Total wt gain } \\
(\mathrm{kg})\end{array}$ & FCR \\
\hline Beetal goat & 69 & 14 & 6 & 30.20 & 41.50 & 163 & 11.29 & - \\
\hline Beetal X Teddy goat & 69 & 14 & 6 & 24.10 & 35.35 & 163 & 11.25 & - \\
\hline Beetal goat & 65 & 201 & $10-12$ & 28.00 & 42.28 & 220 & 14.30 & - \\
\hline Crossbred goat & 60 & 60 & $10-12$ & 20.90 & 32.47 & 193 & 11.57 & - \\
\hline Salt Range lambs & 90 & 16 & $5-6$ & 21.30 & 38.22 & 188 & 18.00 & 8.02 \\
\hline Balkhi lambs & 90 & 18 & $3-4$ & 34.00 & 56.00 & 244 & 22.00 & 9.00 \\
\hline
\end{tabular}

CP: $15-16 \%$, TDN: $71-80 \%$

Source: Sharif and Jabbar, 1999; Khan et al., 1997, 2000, 2006.

Table 13. Proposed potential sheep and goat breeds for meat production in Pakistan.

\begin{tabular}{lcl}
\hline Province & Species & Breed \\
\hline Punjab & Goat & Beetal, Dera Din Panah, Teddy \\
& Sheep & Kajli, Lohi, Salt Range and Thalli \\
Sindh & Goat & $\begin{array}{l}\text { Barbari, Kacchan, Kamori, Jattan, } \\
\text { Pateri }\end{array}$ \\
& Sheep & Dumbi, Kachhi and Kooka \\
NWFP & Sheep & Balkhi \\
Baluchistan & Sheep & Baluchi \\
AJ and K & Sheep & Kail \\
\hline
\end{tabular}

Table 14. Export of meat.

\begin{tabular}{lccc}
\hline Year & $\begin{array}{c}\text { Production } \\
(000 \text { tons })\end{array}$ & $\begin{array}{c}\text { Export } \\
(000 \text { tons })\end{array}$ & $\%$ \\
\hline $2002-03$ & 702 & 1.09 & 0.15 \\
$2003-04$ & 720 & 0.53 & 0.07 \\
$2004-05$ & 740 & 1.90 & 0.25 \\
$2005-06$ & 782 & 4.01 & 0.51 \\
$2006-07$ & 827 & 5.84 & 1.03 \\
\hline
\end{tabular}

Source: MINFAL, 2007.

and $71-80 \%$ Total Digestible Nutrients. Keeping in view the data presented in the above table and the weight gains under traditional farming system, it can be concluded that there is a great potential to bridge the gap between demand and supply.

On the basis of reported birth weight, weaning weight, growth rate/day, mature body weight and dressing percentage, the following small ruminant breeds have potential for meat production (Table 13).

The above-mentioned small ruminant breeds can be used for fattening under the feedlot system.

\section{Export of Mutton and Goat Meat}

Keeping in view the data presented in the Tables 8 and 9 and weight gains under the traditional farming system, it can be concluded that there is a great potential to bridge the yield gap of about $200 \%$ which can be achieved through balanced feeding and management under feedlot farming system.

The data on the export of meat is given in Table 14 . It clearly shows that the demand for Pakistani meat is increasing year by year, especially in the Gulf States.

Keeping in view the generation of more demand for export, efforts should be made to increase meat production by introducing the feedlot fattening system into Pakistan.

\section{Conclusions}

- Annual growth rate of $4 \%$ and $0.8 \%$ was observed in goats and sheep, respectively during 1986-2006.

- Productivity per unit of small ruminant is low under the prevailing production system.

- Higher growth potential in on-farm trials were observed as compared to field observations.

\section{References}

Acharya, R.M. 1988. Goat breeding and meat production. In: Proceedings of a Workshop on the Goat Meat Production in Asia. C. Devendra (Editor), 14-29. Tando Jam, Pakistan.

Anonymous. 2003. TCP/Pak/0168 Livestock Action Plan. Food and Agriculture Organization of the United Nations, Islamabad, Pakistan.

Anonymous. 2006. Agricultural Statistics of Pakistan 2005-06. Government of Pakistan, Ministry of Food, Agriculture and Livestock, Food, Agriculture and Livestock Division (Economic Wing), Islamabad.

Anonymous. 2007. Economic Survey of Pakistan 2006-07, Government of Pakistan, Finance Division, Economic Adviser's Wing, Islamabad.

Ahmed, M.K. and A. Rehman. 1996. Production performance of different sheep breeds under standard 
feeding and management condition. In: Proceedings of Regional Seminar on Small Ruminants. W. Ahmad, M. Nawaz and T. Aziz (Editors), Islamabad, Pakistan.

Alexandre, G., R. Arquet, G. Gravillon, J.L. Weisbecker and N. Mandonnet. 2004. Carcass characteristics of Creole goat of Guadeloupe (FWI) as a function of feeding management. In: Proceedings of Eighth ICG, Abstract, submitted for publication.

Azam, M. 2005. Assessment of Socio-economic impacts of Drought in Pakistan In: Final Report- PCRWR - Ministry of Science and Technology, Islamabad.

FAOSTAT. 2006. FAO Animal Statistics. http://www. faostat.fao.org

Hasnain, H.U. 1985. Sheep and Goats in Pakistan. Animal Production and Health Paper No. 56, FAO, Rome, Italy.

Isani, G.B. and M.N. Baloch.1996. Sheep and Goat Breeds of Pakistan. Press Corporation of Pakistan. P.O. Box 3133, Karachi.

Khan, A.G., A. Azim, M.A. Nadeem and M.A. Khan. 1997. Effect of growth fattening diets on the growth performance of intensified Afghani lambs. Small Ruminant Research 25:39-42.

Khan, A.G., A. Anjum, M A. Nadeem and M. Ayaz. 2000. The effect of formaldehyde treatment of solvent and mechanical extracted cottonseed meal on performance, digestibility and nitrogen balance in lamb. AsianAustralasian Journal of Animal Science 13:785-790.

Khan, A.G., A. Azim and M.I. Anjum. 2003. Prospects of goat as meat animals of Pakistan. In: Proceeding of the International Seminar on Goat Production in SAARC Countries. M. Afzal and R.H. Usmani (Editors), Pakistan Agricultural Research Council, Islamabad.

Khan, H.A. and T.N. Pasha. 1990. Fattening potential of different indigenous breeds of sheep/goats for mutton production.

Khan, M.F., M. Rafiq, F. Ashfaq and M.M. Shahid. 2006. Economic production traits of Balkhi sheep breed for mutton production in Pakistan. In: Proceedings of the $12^{\text {th }}$ AAAP Animal Science Congress, Busan, Korea.

Livestock Census. 1986. Agricultural Census Organization, Statistics Division, Government of Pakistan, Gulberg, Lahore.

Livestock Census. 1996. Agricultural Census Organization, Statistics Division, Government of Pakistan, Gulberg, Lahore.

Livestock Census. 2006. Agricultural Census Organization, Statistics Division, Government of Pakistan, Gulberg, Lahore.

MINFAL. 2007. Ministry of Food, Agriculture and Livestock, Government of Pakistan.

Moniruzzaman, M., M.A. Hashem, S. Akhtar and M.M. Hossain. 2002. Effect of different feeding systems on carcass of Black Bengal goat. Asian-Australasian Journal of Animal Science 15:61-65.

Qureshi, M.A., M. Abdullah, A. Ghaffar and M.F. Khan. 2002. Performance of Kajli sheep at Khizarabad: Production as influenced by some environmental factors. Journal of Animal Production Science 12: 118-121.

Rafiq, M., M.F. Khan and K.M. Aujla. 2003. Economic benefits of flushing and supplemental feeding of salt range ewes on Pothwar ranges of Pakistan. Pakistan Journal of Biological Sciences 6:115-121.

Shah, M.H. and M.F. Khan. 2004. Establishment of a nucleus flock of highest genetic merit for breeding, production and propagation. 25 $5^{\text {th }}$ Annual Report 2003-04. Livestock Production Research Institute, Bahadurnagar, Okara, Pakistan. pp. 48.

Sharif, A. and A. Jabbar. 1999. Personal communication. Livestock Production Research Institute, Bahadurnagar, Okara.

Wilson, R.T. 1992. Goat meat production and research in Africa and Latin America. In: Pre-Conference Proceedings of the 5th International Conference on Goats, New Delhi, March 1992. Invited papers, 2: 458-772. 